\title{
PERAN STRATEGIS KELUARGA DALAM PENDIDIKAN ANAK
}

\section{Oleh : Unang Wahidin}

\section{A. Pendahuluan}

Dalam Islam, keluarga mempunyai peran yang sangat penting dalam kehidupan manusia, baik dilihat dari pandangan individu maupun menurut pandangan masyarakat. Menurut pandangan individu, keluarga merupakan simbol bagi ciri-ciri yang mulia seperti keimanan yang teguh kepada Allah 1 , pengorbanan, kesediaan berkorban untuk kepentingan kelompok, cinta pada kebaikan, kesetiaan dan lain-lain dari nilai mulia yang dengannya keluarga dapat menolong individu untuk menanamkannya kepada dirinya. Menurut pandangan masyarakat, keluarga merupakan institusi sosial yang terpenting dan merupakan unit sosial yang utama. Melalui individu-individu dalam masyarakat dipersiapkan nilai-nilai kebudayaan, kebiasaan dan tradisinya, dipelihara kelanjutannya, dan melalui keluarga juga kebudayaan dipindahkan dari satu generasi ke generasi selanjutnya.

Dengan demikian yang diwarisi oleh anak-anak dari orang tuanya bukan hanya berupa harta benda tetapi juga nilai-nilai yang bermanfaat dalam kehidupan. Jelas kiranya bahwa generasi penerus yang sehat, dinamis dan kreatif diciptakan oleh generasi sebelumnya. Pembangunan dunia ini harus diteruskan secara berkesinambungan dan tidak berhenti dengan matinya seseorang. Ilmu yang bermanfaat perlu dikembangkan secara terus menerus.

Kata Kunci: Peran Kelurga, Pendidikan Anak

\section{B. Pembahasan}

\section{Pendidikan Kehidupan Keluarga}

Pendidikan kehidupan keluarga (Family Life Education) muncul dalam dunia pendidikan didasarkan atas dua fenomena: ${ }^{1}$

Pertama, kehidupan keluarga berpengaruh terhadap kehidupan bermasyarakat, berbangsa dan bernegara.

Kedua, keadaan dan perubahan yang terjadi dalam lingkungan berpengaruh pula terhadap kehidupan keluarga.

Kedua fenomena di atas menunjukkan bahwa kehidupan keluarga senantiasa berhadapan dengan berbagai permasalahan yang berkembang di lingkungan sekitar, sehingga keduanya saling berkaitan. Adapun permasalahan di lingkungan luar keluarga sebagai berikut: ${ }^{2}$

a. Pertambahan penduduk dunia yang terus meningkat.

b. Perpindahan penduduk dari daerah pedesaan ke perkotaan (urbanisasi) di berbagai negara yang mengakibatkan perubahan struktur desa dan perlunya penyesuaian dengan kehidupan masyarakat perkotaan.

c. Perubahan usia dan perkembangan kejiwaan pada penduduk usia muda.

d. Perkembangan standar ekonomi.

e. Kekurangan gizi.

f. Kurang perhatian terhadap kedudukan dan peran wanita.

g. Makin bertambahnya tenaga penganggur dan setengah penganggur.

h. Kondisi perumahan yang kurang memadai.

Djudju Sudjana, Pendidikan Non Formal, Falah Production, Bandung, 2004, hlm. 54.

2 B.J. Brannan, dalam Djudju Sudjana, The Eleventh International Congress on Home Economics, The Mocking bird (Official Publication of the Florida Home Economics Association), Fall 1968. 
i. Kurang kesempatan pendidikan dan bertambahnya kebutuhan untuk meningkatkan kualitas pendidikan pada umumnya.

j. Perubahan sosial, ekonomi, dan teknologi yang makin cepat.

k. Perubahan pola kehidupan keluarga dan perubahan peranan anggota keluarga.

Kehidupan masyarakat yang makin kompleks menekankan kembali pentingnya peranan keluarga sebagai lembaga masyarakat yang tertua di dunia ini. Apabila kehidupan keluarga dibina dengan baik, maka kehidupan masyarakat akan baik pula. Upaya pembinaan keluaga ini tergantung pada kearifan para anggota keluarga yang berusia dewasa, terutama para orang tua, dalam mengembangkan kehidupan keluarga. Upaya yang paling efektif untuk mengembangkan kehidupan keluarga tersebut ialah melalui pendidikan.

\section{Pengertian Keluarga}

Keluarga merupakan lembaga sosial terkecil dalam kehidupan umat manusia sebagai makhluk sosial, ia merupakan unit pertama dalam masyarakat yang terbentuk melalui perkawinan secara sah menurut syara'. Menurut pendapat yang lain (hukum Islam), keluarga sebagai bukti penghambaan kepada Allah $\mathbf{1}$ dan mengikuti sunnah Nabi Muhammad $\mathrm{n}$, demi mengharapkan keridhoan, kecintaan dan perjumpaan dengan-Nya. Sedangkan iktikad (keyakinan) dalam perkawinan adalah keyakinan terhadap Allah $\mathbf{I}$ bahwa dalam perkawinan yang sah itu pasti mengandung hikmah yang besar dan memiliki nilai-nilai ketuhanan. Romantika dan ujian yang terjadi dalam perkawinan merupakan jalan untuk menuju kepada keridhoan, kecintaan, dan perjumpaan dengan-Nya, serta pendewasaan dan pematangan keimanan, keislaman, dan ketauhidan diri ${ }^{3}$.

Keluarga adalah unit pertama dan institusi dalam masyarakat, dimana hubungan yang terdapat di dalamnya sebagian besar sifatnya berupa hubunganhubungan langsung. Di situpulalah berkembangnya individu dan di situlah terbentuknya tahap-tahap awal permasyarakatan (socialization) dan mulai interaksi dengannya, ia memperoleh pengetahuan, keterampilan, minat, nilainilai emosi dan sikapnya dalam hidup, dan dengan itu ia memperoleh ketentraman dan ketenangan. Keluarga adalah pokok pertama yang mempengaruhi pendidikan seseorang. Lembaga keluarga adalah lembaga yang kuat berdiri di seluruh penjuru dunia sejak zaman dahulu. Ia merupakan tempat manusia mula-mula digembleng untuk mengarungi hidupnya.

Menurut Hammudah Abd Al-Ati definisi keluarga dilihat secara operasional adalah: suatu struktur yang bersifat khusus satu sama lain, dalam keluarga itu mempunyai ikatan apakah lewat hubungan darah atau pernikahan. Menurut definisi di atas, keluarga diikat oleh dua hubungan, yaitu hubungan darah dan hubungan pernikahan." Abd. Al-Ati melihat adanya dua posisi dalam struktur keluarga menurut Islam, yaitu posisi utama (primary) dan posisi tambahan (suplementary), yang keduanya saling melengkapi bangunan keluarga dalam Islam. Posisi utama (primary) adalah keluarga dalam tingkatan utama yang terdiri atas ayah, ibu, dan anak. Posisi tambahan (suplementary) adalah

3 Ibnu Qayyim Al-Jawzy, Tuhfah al-Maudud fi Ahkam al-Maulud (Kado Kelahiran), Pustaka Al-Furqan, Yoyakarta, 2007, hlm. 15.

4 Ramayulis, et.al., Pendidikan Islam Dalam Rumah Tangga, Kalam Mulia, Jakarta, 2001, hlm. 1 . 
keluarga pada tingkatan kedua, yang terdiri atas anggota dari keturunan ibu baik ke samping maupun ke atas dan keluarga karena persamaan agama. Bentuk keluarga yang paling sederhana adalah keluarga inti yang terdiri atas suami, istri dan anak-anak yang biasanya hidup bersama dalam suatu tempat tinggal. Sedangkan Suparlan menyatakan bahwa dalam hal-hal tertentu pendefinisian ini tidak dapat dipakai, karena dalam kenyataan ada sejumlah masyarakat yang keluarga intinya tidak lengkap, yaitu karena tidak adanya suami atau istri yang hidup bersama dalam satu rumah. $^{5}$

Suatu keluarga inti dapat juga menjadi keluarga luas dengan adanya tambahan dari sejumlah orang lain, baik yang sekerabat, yang secara bersamaan hidup dalam satu rumah tangga dengan keluarga inti. Orangorang yang sekerabat tersebut bisa berasal dari pihak suami maupun dari pihak istri. Sedangkan orang lain atau orang-orang luar yang dapat mewujudkan adanya keluarga luas dari suatu keluarga inti adalah pembantu rumah tangga atau buruh-buruh dan pesuruh yang hidup bersama keluarga inti yang menjadi majikannya.

Sedangkan pengertian keluarga dalam Islam adalah suatu sistem kehidupan masyarakat terkecil yang dibatasi oleh adanya keturunan (nasab) atau disebut juga ummah akibat oleh adanya kesamaan agama. Pengertian ini dapat dibuktikan dengan melihat kehidupan sehari-hari umat Islam. Misalnya adalah hubungan waris terlihat bahwa hubungan keluarga dalam pengertian keturunan tidak terbatas hanya pada ayah, ibu, dan anak-anak saja, tetapi lebih jauh dari itu, dimana kakek, nenek, saudara ayah, saudara ibu, saudara kandung, saudara sepupu, anak dari anak,

\footnotetext{
5 Ibid., hlm. 2.
}

semuanya termasuk ke dalam saudara atau keluarga yang mempunyai hak untuk mendapatkan waris.

Keluarga sering disebut juga sebagai lembaga pertama dan utama bagi pendidikan anak-anak yang dilahirkan. Disebut lembaga pertama karena setiap anak manusia yang dilahirkan pasti berada dalam sebuah keluarga dan menerima pendidikan pertama dari keluarga sebelum lembaga-lembaga pendidikan lainnya. Pendidikan pertama yang diberikan sesuai dengan sistem pendidikan yang berlaku dimana keluarga tersebut berada. Dan keluarga disebut lembaga utama dalam pendidikan anak, karena keluarga memegang peranan paling penting dalam pendidikan anak yang dilahirkan bila dibandingkan dengan lembaga-lembaga lainnya. Hal ini sesuai dengan sabda Rasulullah П, "Setiap anak terlahir dalam keadaan fitrah, hingga berubah lisannya. Kedua orang tuanya yang merubah menjadi Yahudi, Nashrani atau Majusi." (HR. Bukhori dan Muslim).

Rasulullah $\mathrm{h}$ telah menjelaskan bahwa setiap anak lahir di atas fitrah aqidah tauhid dan condong kepada ketauhidan bahkan jiwa anak secara otomatis terfitrah mengenal penciptanya yang mengadakan sesuatu dari tidak ada menjadi wujud, tidak menyekutukan-Nya dan tidak menyembah kepada selain-Nya, akan tetapi lingkungan (keluarga) yang merubah anak dan menyelewengkan dari asli fitrahnya.

\section{Fungsi-Fungsi Keluarga}

Sekurang-kurangnya ada lima fungsi keluarga, yang bila dilihat dari segi pendidikan akan sangat menentukan kehidupan seseorang: ${ }^{6}$

6 Ramayulis, et.al., Pendidikan Islam Dalam Rumah Tangga, Kalam Mulia, 2001, hlm. 5. 
a. Keluarga dibentuk untuk reproduksi, memberikan keturunan, ini merupakan tugas suci agama yang dibebankan kepada manusia, transmisi pertama melalui fisik.

b. Perjalanan keluarga selanjutnya mengharuskan ia bertanggung jawab, dalam bentuk pemeliharaan yang harus diselenggarakan demi kesejahteraan keluarga, anak-anak perlu pakaian yang baik, kebersihan, permainan yang sehat, makanan yang bergizi, rekreasi dan sarana hidup materil lainnya.

c. Lebih jauh keluarga berjalan mengharuskan ia menyelenggarakan sosialisasi, memberikan arah pendidikan, pengisian jiwa yang baik dalam bimbingan kejiwaan.

d. Preferensi adalah fungsi selanjutnya, karena hidup adalah "just a matter of choice" maka orang tua harus mampu memberikan preferensi yang terbaik untuk anggota kelurganya, terutama anak-anaknya. preferensi adalah tindak lanjut dari sosialisasi. Orang memberikan preferensi jalan mana yang harus ditempuh dalam kehidupan anak.

e. Pewarisan nilai kemanusiaan, yang minimal di kemudian hari dapat menciptakan manusia yang cinta damai, anak shalih yang suka mendoakan kepada orang tua secara teratur, yang mengembangkan kesejahteraan sosial dan ekonomi umat manusia yang mampu menjaga dan melaksanakan hak azasi kemanusiaan yang adil dan beradab yang mampu menjaga kualitas dan moralitas lingkungan hidup.

Sejalan dengan fungsi-fungsi keluarga sebagaimana telah dikemukakan di atas,
Sudjana mengemukakan sembilan fungsi keluarga: ${ }^{7}$

a. Fungsi biologis, yang bertujuan untuk memelihara kesehatan jasmaniah anggota keluarga, memenuhi kebutuhan seksual antara pasangan suami istri, dan untuk memperoleh keturunan.

b. Fungsi edukatif, untuk menumbuhkembangkan keluarga sebagai wahana pendidikan pertama dan paling utama. Dengan fungsi ini terkondisi keluarga yang saling membelajarkan di antara anggota keluarganya sehingga terwujud keluarga gemar membaca dan gemar belajar, atau keluarga berbudaya belajar.

c. Fungsi religis, berkaitan dengan kewajiban orang tua, sebagai pendidik utama, untuk menciptakan iklim keagamaan dalam kehidupan keluarga. Orang tua mempunyai peran utama dalam mengenalkan, membimbing, memberi teladan dan melibatkan anakanak dan anggota keluarga lainnya dalam memahami dan melaksanakan ajaran-ajaran agama dalam kehidupan sehari-hari.

d. Fungsi kasih sayang, menyiratkan bahwa interaksi dalam keluarga dibina atas dasar hubungan emosional dan spiritual yang kondusif untuk tumbuh kembangnya silih asih, silih asah, dan silih asuh. Orang tua menjadi cermin bagi anggota keluarga lainnya dalam interaksi intra keluarga ini. Hubungan orang tua dalam situasi mawaddah wa rahmah menjadi contoh yang baik bagi pengembangan kasih sayang bagi anggota keluarga lainnya.

Djudju Sudjana, Pendidikan Non Formal, Falah Production, Bandung, 2004, hlm. 54. 
e. Fungsi perlindungan (protektif), bertujuan untuk 1) mengembangkan potensi-potensi ketahanan mental dan fisik anak-anak dan anggota keluarga lainnya ke arah yang lebih baik, dan 2) menjaga, memelihara, dan menangkal anak-anak dan anggota keluarga lainnya dari pengaruh negatif yang datang dari luar lingkungan keluarga.

f. Fungsi sosialisasi, yang bertujuan untuk mempersiapkan anak-anak dan anggota keluarga lainnya menjadi anggota masyarakat yang baik yaitu berpartisipasi aktif dan kontributif dalam kegiatan sosial dan pembangunan, harmonis dalam hubungan intra dan antara keluarga, mengakui dan menghargai perbedaan, mencari dan menemukan titik-titik persamaan, serta membina kebersamaan dalam kehidupan bermasyarakat dan berbangsa di atas titik persamaan tersebut.

g. Fungsi ekonomi, memberi makna bahwa keluarga merupakan ekonomi. Aktifitasnya berkaitan dengan upaya mencari nafkah, membina dan mengembangkan usaha keluarga, perencanaan pendapatan dan pengeluaran biaya keluarga. Pada gilirannya, kegiatan dan status ekonomi keluarga dapat mempengaruhi harapan orang tua dan anak-anak terhadap masa depan kehidupan mereka.

h. Fungsi rekreasi, tidak menggambarkan harus adanya kemewahan dalam keluarga melainkan dengan mengkondisikan rumah tangga sehingga tumbuh suasana keluarga yang tenang, sakinah wa rahmah, damai, jauh dari ketegangan rohaniah, harmonis, dinamis dan kreatif. i. Fungsi kepedulian, terhadap lingkungan, baik lingkungan sosial budaya maupun lingkungan alam. Kepedulian terhadap lingkungan sosial budaya bertujuan agar keluarga memperhatikan dan memberikan manfaat secara optimal kepada sesama manusia dan membina serta melestarikan budaya. Kepedulian terhadap lingkungan alam sekitar bertujuan supaya keluarga memahami, menyikapi secara positif, dan melestarikan sumber daya alam baik hayati dan non hayati maupun sumber daya buatan.

Melihat fungsi-fungsi keluarga sebagaimana diuraikan di atas, semakin memperkuat urgensi fungsi keluarga dalam pendidikan. Hal ini sejalan dengan Undang-Undang Sistem Pendidikan Nasional No. 20 Tahun 2003 Bab VI, Pasal 13 Ayat 1, bahwa jalur pendidikan terdiri atas pendidikan formal, non formal, dan informal yang saling melengkapi dan memperkaya. Sehingga keluarga bersamasama dengan pemerintah dan masyarakat mempunyai tanggung jawab yang sama terhadap pendidikan.

\section{Orang Tua Adalah Pendidik Anak}

Islam menganjurkan kepada laki-laki dan wanita agar memilih jodoh yang baik, semata-mata untuk mendapatkan keturunan yang baik dan mulia yang mampu menjadi pemimpin agama dan umat di masa yang akan datang dan anak-anak shalih yang diharapkan bersama.

Seorang pendidik yang tulen adalah orang tua yang mempersiapkan pendidikan bagi anak-anaknya sejak dini, dengan memulai tahapan dalam mendidik dan membesarkan anak-anak, karena masa itulah masa pertumbuhan anak yang paling 
penting dalam membentuk pribadi dan garis-garis besar corak kepribadian anak dan masa kanak-kanak hingga dewasa. Isteri adalah peneduh hidup sang suami, ladang bagi pertumbuhan anak, pemelihara rumah tangga, ibu bagi anak-anak, belahan hati sang suami dan tempat menyimpan seluruh rahasia hidup dan keluhan batin serta dialah penyangga rumah tangga yang paling strategis.

Isteri adalah ibu, pendidik dan guru serta penyangga keluarga, bila isteri baik maka keluarga akan menjadi baik. Isteri ibarat bumi yang subur tempat untuk menyemai dan menumbuhkan anak didik, jika memilih bumi yang tepat dan bagus maka telah menjatuhkan pilihan bagus dan menyemai bibit di ladang yang subur yang siap membentuk keluarga yang shalih sehingga bisa membantu terbentuknya masyarakat yang baik.

Isteri bertugas melahirkan anak, sementara anak mengambil kebiasaan dan sifat-sifat serta prinsip hidup dari ibu, maka gaya hidup, pola berfikir, keahlian, ketrampilan, kebiasaan, karakter dan kematangan hidup anak sangat tergantung kepada kebiasaan, akhlak dan pola berfikir serta gaya hidup seorang ibu. Maka dialah yang mengajarkan kepada anak berbagai macam ajaran agama, adat, kebiasaan dan etika dalam hidup pribadi dan bermasyarakat. Karena tujuan tersebut, maka sistem Islam sangat menganjurkan kepada umatnya agar memilih isteri yang shalihah sebab wanita shalihah termasuk sebaik-baik kenikmatan dunia. Hal ini berdasarkan hadits riwayat Muslim dan anNasa'i dari Nabi . yang bersabda, "Dunia adalah kenikmatan dan sebaik-baik kenikmatan dunia adalah wanita shalihah" (HR. Muslim). Dan telah diriwayatkan oleh Ibnu Majah dan Abu Umamah $\mathbf{h}$. bahwa Nabi Muhammad $\boldsymbol{n}$. bersabda,
"Tidak ada perkara yang lebih baik bagi seorang mukmin setelah bertakwa kepada Allah daripada isteri yang shalihah, bila ia menyuruhnya maka ia menaatinya, bila ia memandangnya membuat hati senang, bila ia bersumpah maka ia menolong menunaikannya dan bila ia pergi maka ía dengan tulus menjaga agama dan harta suaminya." (HR. Ibnu Majah). Dan juga dalam Shahih al-Bukhari disebutkan bahwa Nabi $\bigcap$ bersabda, "Wanita dinikah karena empat perkara, karena hartanya, nasabnya, kecantikannya dan agamanya, maka pilihlah yang memiliki agama, (jika tidak), engkau akan binasa." (HR. Bukhori dan Muslim)

Keluarga merupakan pondasi utama dan tempat strategis untuk membentuk kader bangsa dan pembinaan anggota masyarakat muslim, maka harus hati-hati dan tepat dalam memilih isteri karena itu adalah asas terbentuknya keluarga dan masyarakat muslim yang tangguh dan kokoh.

Banyak kasus dan masalah rumah yang muncul akibat jauhnya dari sistem Islam bahkan sering rumah tangga berantakan dan bahtera rumah tangga pecah karena menjauh dari sistem dan nilai ajaran Islam yang mulia. Sementara anak-anak mengalami broken home dan hidup liar karena tidak komitmen dengan sistem Islam pada saat memilih pasangan hidup. Istri yang sholihah atau suami yang shalih sebagai teman berjuang dalam mendidik anak dan membentuk keluarga yang shalih.

Memilih pasangan hidup atas dasar pilihan yang benar, tepat dan sejalan dengan sistem Islam serta ajaran yang dibawa oleh Rasulullah $\bigcap$, para sahabat dan para tabiin serta kalangan ulama assalafush shalih, maka akan menjadi pondasi kokoh yang bisa melindungi dari berbagai 
kesalahan dengan taufik dan hidayah dari Allah 1 .

Bimbingan orang tua apalagi pada masa usia kanak-kanak merupakan masa bagi anak memiliki kemampuan yang sangat besar dalam menghafal, meniru dan masa cinta bermain. Hendaknya para orang tua memanfaatkan peluang ini sebaik mungkin sesuai pengarahan Umar bin alKhaththab $\mathrm{A}$. "Ajarilah anakmu beberapa nilai kebaikan," adalah mengarahkan anak agar menghafal al-Qur'an, as-Sunnah dan masalah fikih dan beberapa pendapat para ulama. Orang tua harus membuat permainan anak yang bagus dan mendidik serta mengembangkan daya nalar dan kreatifitas anak terutama kemampuan untuk meniru dan menghafal harus diberdayakan semaksimal mungkin.

Orang tua juga harus mampu menjadikan sejarah dan kisah-kisah Islami sebagai media pendidikan bagi anak yang harus disesuaikan dengan umur dan daya pikir serta kepribadian anak sehingga anak tumbuh secara sempurna dan alami baik dari sisi intelegensi, fisik, sosiologi, prilaku dan keagamaan.

Bila anak terbiasa dengan etika, akhlak dan nilai-nilai yang baik sejak masa kecil maka ia tumbuh besar dan akrab dengan nilai dan kebiasaan mulia dan baik, sehingga anak akan dengan rnudah diarahkan dan dididik kepada kebaikan dan kemuliaan serta masa tua tinggal menikmati hasilnya karena masa tua terbiasa dengan kondisi di masa kecil.

Sistem Islam menganjurkan kepada setiap orang tua agar mendidik anak dengan penuh kasih sayang, lemah lembut dan pergaulan yang baik, dan memberi peringatan keras agar tidak teledor dan

8 Al-Maghribi bin as-Said al-Maghribi, Kaifa Turabbi Waladan (Begini Seharusnya Mendidik Anak), Darul Haq, Jakarta, 2004, hlm. 135. menyia-nyiakan amanah serta menipu dalam masalah tanggung jawab dalam pendidikan anak. Allah $\mathbf{1}$ berfirman dalam Al Qur'an surat An-Nisa ayat 58 yang berbunyi:

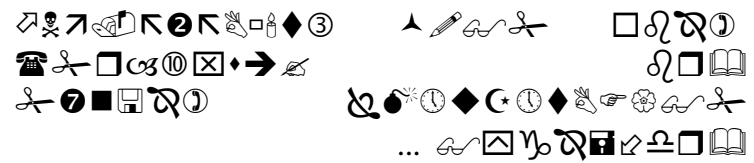

"Sesungguhnya Allah menyuruh kalian menyampaikan amanat kepada yang berhak menerimanya."

Allah 1 juga berfirman dalam $\mathrm{Al}$ Qur'an Surat At-Tahrim ayat 6, yang berbunyi:

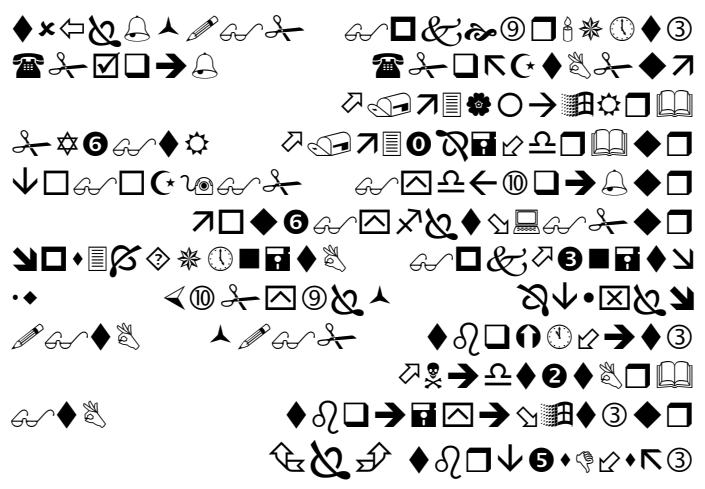

"Hai orang-orang yang beriman, peliharalah diri kalian dan keluarga kalian dari api neraka yang bahan bakarnya adalah manusia dan batu; penjaganya malaikat-malaikat yang kasar, yang keras yang tidak mendurhakai Allah terhadap apa yang diperintahkan Nya kepada mereka dan selalu mengerjakan apa yang diperintahkan."

Sedangkan Abu Ya'la Ma'qil bin Yasar a berkata, "Aku mendengar Rasulullah $\mathrm{h}$ bersabda, "Tidaklah seorang hamba yang diberi tanggung jawab oleh Allah 1 sebuah amanah lalu ia meninggal dalam keadaan menipu tanggung jawabnya kecuali Allah $\mathbf{1}$ akan mengharamkan surga baginya." (HR. Bukhori dan Muslim). Dalam suatu riwayat, "Tidak tulus dalam menunaikan tanggung jawab 
maka ia tidak akan mendapatkan aroma surga."

Orang tua wajib mengajarkan kepada anak-anak tentang nilai tauhid. Ajarilah anak-anak untuk mengucapkan "Tuhanku adalah Allah 1 yang menciptakanku dan menciptakan semua manusia dan semua makhluk serta menciptakan siang, malam, matahari dan bulan. Dialah yang menurunkan hujan dari langit." Orang tua wajib mengajarkan kepada anak-anak bahwa agama yang paling benar adalah Islam, karena Islam merupakan agama untuk mentauhidkan Allah $\mathbf{1}$, menaati-Nya dan tidak menyelisihi perintah-Nya. Prinsip Islam dibangun di atas dasar kesaksian bahwa tiada Tuhan yang berhak disembah selain Allah 1 dan Muhammad $\boldsymbol{n}$ adalah utusan Allah 1 yang diutus kepada seluruh manusia untuk mengajarkan Islam kepada mereka dan mengajak kepada ibadah dan tauhid kepada Allah 1 serta meninggalkan seluruh sembahan selain-Nya.

\section{Tugas dan Kewajiban Orang Tua}

Sesungguhnya tugas dan kewajiban orang tua untuk membimbing anakanaknya mempunyai beberapa landasan motivasi, yaitu: ${ }^{9}$

a. Bahwa hal tersebut adalah sebagai tujuan hidup manusia, agar mempunyai keturunan yang dapat dibanggakan, tidak hanya sekedar melahirkan anak saja.

b. Anak adalah sebagai amanat Allah 1 kepada orang tua, yang tentu saja tidak boleh ditelantarkan begitu saja.

c. Karena anak adalah sebagai amanat dari Allah 1 maka dengan sendirinya juga sebagai cobaan dari Allah 1 juga, apakah nantinya yang kita perbuat

9 Umar Hasyim, Cara Mendidik Anak Dalam Islam, Bina Ilmu, 1983, hlm. 147-150. terhadap anak kita. Karena bila kita tidak berbuat dan bertindak benar, maka kita bisa masuk neraka karena anak.

d. Telah banyak bukti di hadapan kita, bahwa anak memusuhi orang tua karena salah didik.

e. Untuk itu semua, harapan kita adalah agar anak-anak kita menjadi anak yang shalih. Sebab bila tidak, orang tua menganggap anak hanya sebagai kebanggaan saja tanpa membimbing dan mendidiknya, dan hal ini bisa menyebabkan orang tua lupa kepada Allah 1 dan Rasul-Nya hanya karena pasal anak saja. Tentang tugas dan kewajiban orang tua, dalam sebuah hadits diriwayatkan oleh Imam Hakim menyebutkan bahwa Rasulullah $\mathrm{n}$ bersabda: "Kewajiban orang tua terhadap anaknya adalah: (1) Memberi nama yang baik; (2) Membaguskan (mengajar) akhlaknya; (3) Mengajar baca tulis; (4) Mengajar renang; (5) Mengajar memanah atau menembak (keterampilan); Memberi makan yang halal; dan (7) Menjodohkannya (menikahkan) bila dewasa.

\section{Kesimpulan}

Orang tua mempunyai peranan penting dalam pendidikan baik dalam lingkungan masyarakat Islam maupun non Islam. Keluarga merupakan tempat pertama kali bagi pertumbuhan dan perkembangan anak yang dimana ia mendapatkan pengaruh dari anggota keluarga yang lain dan masa ini merupakan masa-masa kritis dalam perkembangan dan pertumbuhan baik jasmani dan rohaninya, karena apa yang orang tua tanamkan dalam diri anak pada masa tersebut akan sangat membekas 
pada diri anak dan tidak mudah hilang atau berubah sesudahnya.

\section{Daftar Pustaka}

Al-Jawzy, Ibnu Qayyim, Tuhfah alMaudud fi Ahkam al-Maulud (Kado Kelahiran), Pustaka Al-Furqan, Yoyakarta, 2007.

Al-Maghribi bin as-Said al-Maghribi, Kaifa Turabbi Waladan (Begini Seharusnya Mendidik Anak), Darul Haq, Jakarta, 2004.
Brannan, B.J., dalam Djudju Sudjana, The Eleventh International Congress on Home Economics, The Mocking bird (Official Publication of the Florida Home Economics Association), Fall 1968.

Hasyim, Umar, Cara Mendidik Anak Dalam Islam, Bina Ilmu, Jakarta, 1983. Ramayulis, dkk, Pendidikan Islam Dalam Rumah Tangga, Kalam Mulia, Jakarta, 2001.

Sudjana, Djudju, Pendidikan Non Formal, Falah Production, Bandung, 2004. 